\title{
Revealing the presence of Campylobacter jejuni in Chicken Meat by Polymerase Chain Reaction in Different Parts of Chennai, India
}

\author{
S. Satheesh Raja* , V. Apparao, R. Narendra Babu and N. Balamurugan
}

Department of Meat Science and Technology, Madras Veterinary College, Chennai, India

*Corresponding author

\section{A B S T R A C T}

Keywords

C. jejuni,

Polymerase Chain

Reaction, Chennai,

Chicken meat

Article Info

Accepted:

08 June 2018

Available Online:

10 July 2018
Campylobacteriosis is a food-borne bacterial illness due to the consumption of poultry meats and its by-products. Due to improper slaughtering method, carcass may get contaminated with intestinal contents. A study was conducted to identify the presence of Campylobacter jejuni in chicken meat by polymerase chain reaction. 36 samples were collected from different parts of Chennai and were tested for the presence of Campylobacter jejuni by targeting Hyp gene with 500bp by PCR. None of the samples were shown to be positive for Campylobacter jejuni. The test concludes that the processing of chicken was done in perfect manner without any cross contamination.

\section{Introduction}

Campylobacter jejuni are found in domestic animals and also in raw poultry meat (Humphrey et al., 2007). Poultry is the main source of the genus Campylobacter. Campylobacter jejuni have been found in many poultry flocks. However, birds not affected with Campylobacteriosis may also become contaminated during the course of slaughter (Stern et al., 1994). Campylobacter jejuni is present in the gastro intestinal tract of all animals. Contaminated raw or undercooked poultry meats and/or by-products are particularly important to cause food-borne
Campylobacteriosis in humans (CDC, 2005). The raw chicken meat has very high campylobacter contamination levels. Campylobacter spp. was found in higher levels in carcass-rinse or carcass-rinse plus whole skin samples (Jorgensen et al., 2002). Polymerase chain reaction (PCR) is a rapid method with both high sensitivity and specificity for rapid detection and identification of pathogenic bacteria from different food matrix. Hence, the present study is undertaken for detection of Campylobacter jejuni from chicken by using polymerase chain reaction in different zones of Chennai. 


\section{Materials and Methods}

Chicken meat samples of around 40 numbers were collected from different retail outlets of Chennai city. The samples placed in sterile polythene bags and transported hygienically to the Department of Meat Science and Technology, Madras Veterinary College, Chennai -7 in clean insulated box with ice packs. Before screening, 25 gram of meat sample was homogenized in $225 \mathrm{ml}$ of BPW and incubated at $37^{\circ} \mathrm{C}$ for 18 hours. The meat homogenate obtained was then subjected to DNA extraction using Bacterial DNA extraction kit and PCR analysis for the presence of $C$. jejuni by targeting Hyp gene with 500bp. A $20 \mu \mathrm{l}$ of reaction mixture was set up in $0.2 \mathrm{ml}$ PCR tube with following components such as master mix - 10 $\mu$, forward primer-1 $\mu \mathrm{l}$, reverse primer-1 $\mu \mathrm{l}$, template DNA-1 $\mu \mathrm{l}$ and nuclease free water-7 $\mu$ l. The PCR amplification was carried out in Master Cycler Gradient Thermo cycler (M/s. Eppendorf, Germany) with the following cycling conditions of initial denaturation at $94^{\circ} \mathrm{C}$ for 5 minutes, followed by 30 cycles of denaturation $\left(94^{\circ} \mathrm{C}\right.$ for 30 seconds), annealing $\left(52^{\circ} \mathrm{C}\right.$ for 30 seconds) and extension $\left(72^{\circ} \mathrm{C}\right.$ for 30 seconds) and subsequently a final extension at $72^{\circ} \mathrm{C}$ for 7 minutes. The PCR product obtained was subjected to electrophoresis in 2\% Agarose gel. Ethidium bromide with concentration of $10 \mathrm{mg} / \mathrm{ml}$ was added at the rate of $5 \mu \mathrm{l} / 100 \mathrm{ml}$ of Agarose. Electrophoresis is carried out using $1 \mathrm{X}$ TAE buffer at 100 volts for 30 minutes. The gel was viewed under UV illuminator and documented using gel documentation system.

\section{Results and Discussion}

Around 36 chicken meat samples were collected from different retail outlets of Chennai. The meat homogenate obtained was subjected to DNA extraction using Bacterial DNA extraction kit and the developed PCR was used to detect Campylobacter jejuni. None of the sample showed positive for the presence of Campylobacter jejuni in the retail chicken meat by PCR (Figure 1 and 2). Screening of chicken meat from different zone wise details were given below (Table. 1).

Table.1 Screening of chicken meat samples collected from different retail outlets of Chennai

\begin{tabular}{|c|c|c|c|}
\hline Zone & Name & No. of & No. of positive samples by m-PCR \\
\cline { 3 - 4 } & & samples & Campylobacter jejuni \\
\hline $\mathbf{1}$ & Thiruvottiyur & 6 & - \\
\hline $\mathbf{2}$ & Madhavaram & 6 & - \\
\hline $\mathbf{3}$ & Royapuram & 6 & - \\
\hline $\mathbf{4}$ & Ambattur & 6 & - \\
\hline $\mathbf{5}$ & Anna nagar & 6 & - \\
\hline $\mathbf{6}$ & Teynapet & 6 & - \\
\hline & Total & $\mathbf{3 6}$ & 0 \\
\hline
\end{tabular}




\section{Figure.1}

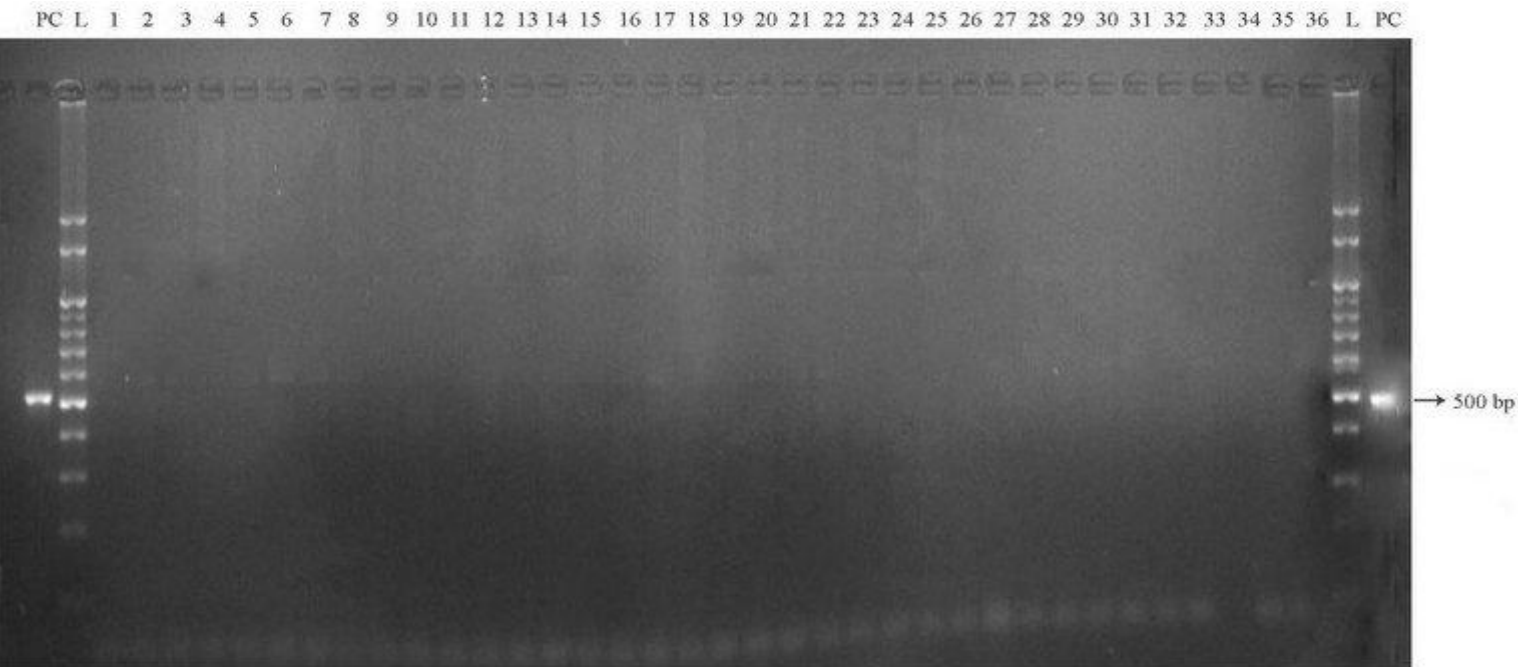

Note: L: 100 bp DNA Ladder, 1-36: Sample result showing absence of Campylobacter jejuni in chicken meat, PC: Positive control of Campylobacter jejuni with 500bp, NC: Negative control

This study states that screening of chicken meat samples from retail outlets were carried out to assess the usefulness of the PCR technique and the level of processing of retail chicken meat. The 36 chicken meat samples collected from different areas of Chennai city were not positive for Campylobacter jejuni. (Rahimi et al., 2010)He found higher prevalence of Campylobacter $(61.7 \%)$ in chicken meat from retail markets of Iran. A study was conducted and found that the level of contamination of poultry meat with Campylobacter jejuni was 50.9\% (Atanassova and Ring, 1997). Around 1 in 1000 infections leads to Guillain-Barre syndrome (GBS), the risk increased to around 1 in 200 for patients infected with a particular $C$. jejuni, Penner type HS:19 (Nachamkin, 2002). An overlap of $34 \%$ between sero-/genotype combinations in sporadic $C$. jejuni infections in chicken flocks at slaughter during a seasonal peak (Karenlampi et al., 2003).

\section{Acknowledgments}

I am very much thankful to all my Department staffs and my friends and colleagues who have helped me in collecting samples from different areas of Chennai.

\section{References}

Atanassova, V., and Ring, Ch. 1997. Campylobacter spp. in slaughter poultry and in hunted game fowl. World congress on Food Hygiene. WAVFH. The Hague, August 24-29, 1997. Proceedings. Wageningen Pers. Wagenigen, 1997, 193.

Centre for Disease Control and Prevention (CDC), 2005.

Humphrey, T., Sarah, O.B. and Mogens, M. 2007. Campylobacters as zoonotic pathogens: A food production perspective. International Journal of Food Microbiology, 117: 237-257.

Jorgensen, F., Bailey, R., Williams, S., Henderson, P., Wareing, D.R., Bolton, F.J., Frost, J.A., L. Ward, L. and Humphrey, T.J, 2002. Prevalence and numbers of Salmonella and Campylobacter spp. on raw, whole chickens in relation to sampling methods. International Journal of 
Food Microbiology, 76: 151-164

Karenlampi, R., Rautelin, H., Hakkinen, M. and Hanninen, M.L. 2003. Temporal and geographical distribution and overlap of Penner heat-stable serotypes and pulsed-field gel electrophoresis genotypes of Campylobacter jejuni isolates collected from humans and chickens in Finland during a seasonal peak. Journal of Clinical Microbiology, 41: 4870-4872.

Nachamkin, I., (2002) Chronic effects of Campylobacter infection. Microbes and Infection, 4: 399- 403.

Rahimi, E., Kazemeini, H.R., Saman, S., Karim, A., Momeni, M. and Riahi, M. 2010. Detection and identification of Campylobacter spp. from retail raw chicken, turkey, sheep and goat meat in Ahvaz, Iran. African Journal of Microbiology Research, 4: 1620-1623.

Stern, N. J., Jones, D.M., Weslex, I.V. and Rolins, D.M. 1994. Colonisation of chick by non-culturable Campylobacter spp. Letters in Applied. Microbiology, 18: 33-36.

\section{How to cite this article:}

Satheesh Raja, S., V. Apparao, R. Narendra Babu and Balamurugan, N. 2018. Revealing the presence of Campylobacter jejuni in Chicken Meat by Polymerase Chain Reaction in Different Parts of Chennai, India. Int.J.Curr.Microbiol.App.Sci. 7(07): 978-981. doi: https://doi.org/10.20546/ijcmas.2018.707.118 